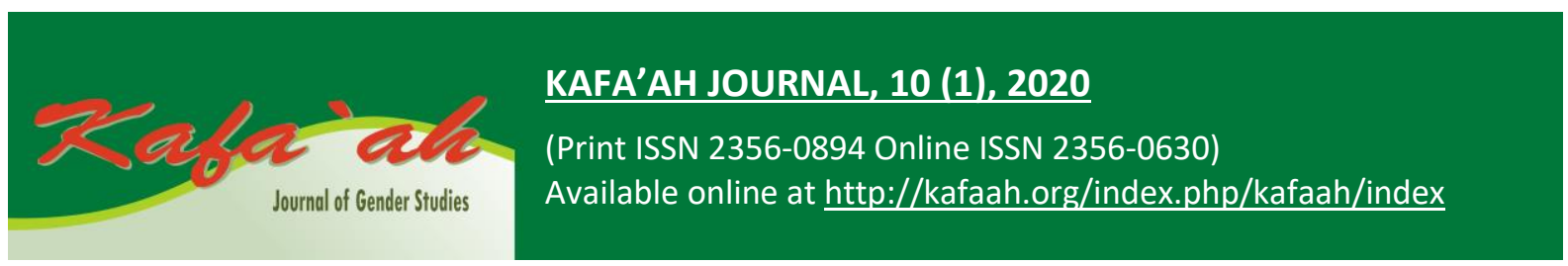

\title{
MENELISIK HAK-HAK PEREMPUAN
}

\author{
Lathifah Munawaroh \\ UIN Walisongo Semarang, Indonesia \\ E-mail: lathifah.munawarah@walisongo.ac.id \\ Suryani \\ IAIN Lhokseumawe, Indonesia \\ E-mail: suryapijar@yahoo.com
}

\begin{abstract}
This paper analyzes women's rights in the thematic interpreter of Surat al-Nisā'. One of the surahs of the Qur'an which uses the name al-Nisā' and is enshrined by Allah as one of the Surahs of the Qur'an. Surat al-Nisä' means "the women" is a form how Islam respect to women. The name of this surah is "the Women" because the discussions about womanhood are more discussed in this surah than in other surahs. The thematic interpretation of this surah is so important, because this surah is targeting the issues of women who are usually regarded as the marginalized part. The method used is to use a thematic interpretation method, as one form of contemporary interpretation method with the use of classical references such as the books of Tafsìr bil Ma'tsūr about Sura alNis $\bar{a}$. The results of this study explain that there are many rights related to women in Surat al-Nisa't: equality rights with men are a central issue in this surah. In addition, there are other women's rights: the right to choose a spouse and the right to inherit and fair treatment. These rights were existed long ago in the beginning of Islam, at a time when women's rights were castrated, not even seen as noble creatures when compared to men.
\end{abstract}

Keywords: the thematic interpreter, Surat al-Nisā', family law, women's rights

\begin{abstract}
Abstrak
Tulisan ini menganalisis tentang hak-hak kaum perempuan dalam kaca mata tafsir tematik surat al-Nisā'. Salah satu surat al-Qur'an yang memakai nama al-Nisā'dan diabadikan oleh Allah sebagai salah satu surat al-Qur'an. Surat al-Nisā'atau yang berarti kaum perempuan ini Allah adakan sebagai salah bentuk penghormatan agama Islam kepada kaum perempuan. Pembahasan tentang keperempuanan lebih banyak dibahas dalam surat ini dibanding dalam surat lainnya. Tafsir tematik tentang surat ini begitu penting, karena salah satunya membidik kaum perempuan yang biasanya dianggap sebagai bagian yang termarjinalkan. Metode yang digunakan adalah dengan menggunakan metode tafsir tematik, sebagai salah satu bentuk metode tafsir kontemporer dengan tetap menggunakan referensi kitab klasik di antaranya adalah kitab-kitab tafsīr bil ma 'tsūr tentang surat al-Nisā'. Hasil dari penelitian ini menerangkan bahwa terdapat banyak hak yang terkait perempuan dalam surat al-Nisā': hak kesetaraan dengan kaum laki-laki yang menjadi isu sentral dalam surat ini. Selain itu, terbaca pula dalam surat ini hak-hak kaum perempuan yang lain yaitu hak memilih pasangan dan hak untuk mendapatkan warisan dan perlakuan adil. Hak-hak ini telah ada jauh pada awal mula Islam datang, pada masa di mana hak-hak kaum perempuan terkebiri, bahkan tidak dipandang sebagai makhluk yang mulia bila dibanding dengan kaum laki-laki.
\end{abstract}

Kata Kunci: tafsir tematik, surat al-Nisā', hukum keluarga, hak-hak kaum perempuan. 


\section{PENDAHULUAN}

Perempuan sebagai salah satu makhluk Allah, yang sejatinya sejajar dengan kaum lakilaki. Perbedaan biologis antara keduanya tidak dapat menjadikan kaum perempuan menjadi makhluk kelas dua. Sering kali dalam realita kehidupan, kaum perempuan menjadi bahan penindasan atas kelemahan mereka, karena dianggap bahwa kaum laki-laki sebagai kepala keluarga merasa menjadi nomor satu yang tidak dapat ditandingi. Sehingga karena kelemahan ini, mereka sering tertindas baik fisik atau psikisnya. Padahal, perbedaan fisik antara keduanya menjadikan keduanya menjadi makhluk yang saling melengkapi, saling membutuhkan satu sama lain, sehingga kehidupan harmoni dapat tercipta.

Tema tentang kesetaraan gender menjadi wacana yang sudah lama digemborkan oleh khalayak ramai, bermula dari kalangan awam, kalangan akademisi, hingga praktisi, bahkan sampai dengan politisi atau pejabat publik. Walau gaungnya telah lama, namun bahasan ini selalu saja hadir dengan berbagai macam pembahasan yang baru maupun pembahasan yang lama yang diperbaharui. Ini menunjukkan bahwa wacana kesetaraan gender ini selalu menarik untuk dibahas. Di sisi lain, diskursus tentang hak-hak perempuan telah muncul sebagai masalah yang sangat penting dikarenakan konon selama ribuan tahun perempuan terus menerus berada di bawah kekuasaan laki-laki dalam suatu mayarakat patriarchal. Hal ini berjalan selama berabad-abad, "hukum alam" ini menetapkan kaum perempuan sebagai komunitas kelompok kelas dua (the second rate communities) secara sosial, kaum ini lebih rendah dari laki-laki dan mereka harus tunduk kepada kekuasaan laki-laki dan hegemoni mereka demi kelancaran dan kelestarian kehidupan keluarga (Tahir, 2016). Di samping itu, dikarenakan dalam kehidupan bermasyarakat sering kali mendapatkan diskriminasi baik dalam kehidupan pekerjaan, relasi suami istri atau dalam tataran kehidupan bermasyarakat (Cholil \& Sudirman, 2019).

Gaung emansipasi atau permintaan pengakuan hak-hak kaum perempuan sudah lama di permukaan. Mereka menuntut persamaan hak dengan kaum laki-laki, tanpa diskriminasi. Pembahasan hak perempuan sebagai perwujudan dari hak asasi manusia semakin menguat dari waktu ke waktu. Hal ini terjadi karena banyaknya perempuan yang menjadi korban. Di samping itu, kaum perempuan juga mulai kritis melihat persoalan hak-hak mereka. Tidak hanya menerima keadaan, mereka juga mulai mencari cara bahkan menuntut adanya jaminan pemenuhan hak-hak perempuan (Agustina, 2017). Padahal, jauh sebelum ini agama Islam telah mengakui hak-hak kaum perempuan di banyak teks agamanya. Islam membawa prinsip keadilan sosial bagi kelompok-kelompok yang lemah, dan kaum perempuan masuk dalam barisan ini (Cholil \& Sudirman, 2019). Salah satunya adalah dalam QS. al-Nisā'. Agama Islam sebagai syariat dan pedoman hidup yang terpadu serta komprehensif ini menganggap bahwa setiap manusia yang mendapatkan beban (taklif) sama, tidak memandang remeh salah satu makhluk-Nya. Semua yang mendapat takliff dalam posisi mulia baik ia laki-laki ataupun perempuan. Karena sejatinya adalah unsur pokok dalam pemakmuran hidup di dunia ini. Hal ini tegas dinyatakan Allah di banyak tempat dalam al-Quran, salah satunya dalam surah alAḥzāb (33): 35 yaitu:

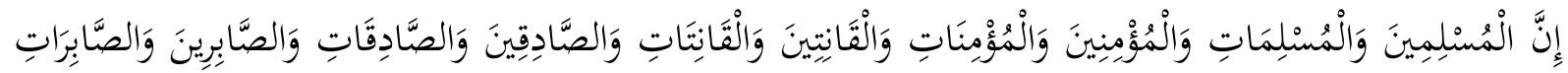

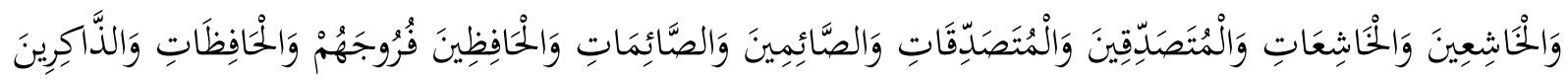

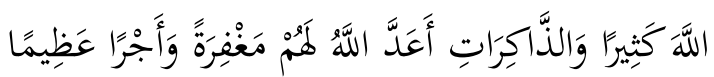

"Sesungguhnya laki-laki dan perempuan muslim, laki-laki dan perempuan mukmin, laki-laki dan perempuan yang tetap dalam ketaatannya, laki-laki dan perempuan yang benar, laki-laki dan perempuan yang sabar, laki-laki dan perempuan yang khusuk, laki-laki dan perempuan yang bersedekah, laki-laki dan perempuan yang 
berpuasa, laki-laki dan perempuan yang memelihara kehormatannya, laki-laki dan perempuan yang banyak menyebut (nama) Allah, Allah telah menyediakan untuk mereka ampunan dan pahala yang besar".

Dalam ayat ini telah jelas bahwa derajat keduanya sama di sisi Allah. Keduanya, baik laki-laki dan perempuan memiliki kesempatan yang sama dalam berbuat kebaikan dan mendapat pahala dari Allah, tanpa ada perbedaan (Sarbini, 2017). Di sini diperlukan pula kesadaran perempuan muslim untuk berperan aktif dalam dinamika kehidupan bermasyarakat yang terbangun dari pemahaman mereka tentang nilai-nilai Islam yang komprehensif, sebagai buah dari proses pendidikan Islam. Islam yang mereka pahami dalam dimensinya yang utuh sebagai way of life, membangkitkan kesadaran akan amanah untuk menegakkan risalah itu sebagai tiang utama peradaban dunia (Rusli, 2011). Sarbini (2017) menyimpulkan dalam penelitiannya bahwa wanita adalah saudara kandung pria, dan ini memiliki hikmah yang sangat banyak, di antaranya adalah untuk bersama-sama memakmurkan bumi dengan syariatNya dan penjabaran tentang hak dan tugas kaum perempuan dalam fiqih Islam dapat dilihat secara cermat. Tulisan ini menganalisis tentang hak-hak kaum perempuan dalam kaca mata tafsir tematik surat al-Nisā'. Salah satu surat al-Qur'an yang memakai nama al-Nisā' dan diabadikan oleh Allah sebagai salah satu surat al-Quran. Surat al-Nisā' atau yang berarti kaum perempuan ini Allah adakan sebagai salah bentuk penghormatan agama Islam kepada kaum perempuan. Pembahasan tentang keperempuanan lebih banyak dibahas dalam surat ini dibanding dalam surat lainnya. Tafsir tematik tentang surat ini begitu penting, karena salah satunya membidik kaum perempuan yang biasanya dianggap sebagai bagian yang termarjinal.

\section{METODE PENELITIAN}

Metode yang digunakan adalah dengan menggunakan metode tafsir tematik, sebagai salah satu bentuk metode tafsir kontemporer dengan tetap menggunakan referensi kitab klasik di antaranya adalah kitab-kitab tafsīr bil ma 'tsūr tentang surat al-Nisā'.

\section{HASIL DAN PEMBAHASAN}

\section{Overview Surat Al-Nisā'}

Surat-surat dalam al-Qur'an sering kali memiliki lebih dari satu nama. Surat al-Fātihah contohnya, surat ini memiliki nama lain, yaitu Umm al-Kitab, Umm al-Qur'an, al-Sab'u alMatsāni. Demikian pula dengan Surat al-Nisā'. Ia memiliki nama-nama selain surat al-Nisā', dengan nama yang paling popular yaitu surat al-Nisā'. Al-Qāsimiy menjelaskan tentang sebab surat ini dinamakan dengan surat al-Nisā', dikarenakan hukum-hukum terkait masalah perempuan lebih banyak dibahas dalam surat ini jika dibanding dengan surat-surat lain dalam al-Qur'an. Selain itu, dalam surat ini dimulai dengan hukum-hukum tentang silaturrahim, lalu hukum-hukum khusus terkait dengan kaum perempuan seperti pernikahan, anak-anak perempuan, dan hukum-hukum lain tentang keperempuanan (Qasimy, 1998). Nama al-Nisā' ini adalah nama yang disebut-sebut oleh ulama' terdahulu. Hal ini seperti yang disebutkan oleh al-Bukhāri dari Aisyah, bahwa Ia berkata: "Surat al-Baqarah dan Surat al-Nisā' tidak turun kecuali aku berada di sisi Rasulullah" (Ibnu 'Āshūr, 1984). Begitu pula nama inilah yang tertera di mushaf, dan juga pada kitab-kitab hadis dan kitab tafsir, dan tidak diketahui nama selainnya" (Ibnu 'Āshūr, 1984). Namun ternyata terdapat dalam Sahih al-Bukhari dari Ibnu Mas'ud, bahwa Nabi bersabda: "Telah turun surat al-Nisa $\bar{a}$ ' al-Qushra”, yang dimaksud di sini adalah surat al-Talāq yang juga berisi tentang perempuan. Sehingga nama surat al-

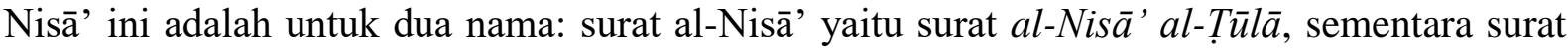
al-Talāq disebut juga surat al-Nisā' al-Qushrā. Al-Fairuzzabādi mengatakan bahwa surat alNisā' ini dinamakan dengan surat al-Nis $\bar{a}^{\prime}$ al-Kubrāa, sementara surat al-Talāq adalah surat alNis̄à' al-Sughrä’' (Ibnu 'Āshūr, 1984). 
Diambil dari penjelasan Ibnu 'Āsyūr di atas dapat disimpulkan bahwa nama surat alNisā' tidak diketahui nama selain itu, dan bahwa Ibnu Āsyūr tidak mendapatkan nama surat al-Nisā' dengan surat al-Nis $\bar{a}$ ' al-Ṭ̂ula , dan hanya al-Fairuzabadi saja yang menyebutkan bahwa surat al-Nisā' ini dinamakan dengan surat al-Nis̄̄' al-Kubrā. Dari sini pula, diketahui bahwa nama lain surat al-Nisā' sebagian ada yang menyebut dengan nama surat al-Nisă ${ }^{\prime}$ alȚūla dan surat al-Nis $\bar{a}$ ' al-Kubrāa, untuk membedakannya dengan surat al-Ṭalāq. Selain namanama di atas, surat al-Nisā' memiliki nama lain lagi yaitu Surat al-Aḥkām yang dipakai oleh al-Sam'āni dalam tafsirnya, karena dalam surat al-Nisā' di sini terkandung banyak hukumhukum syariat bagi kaum muslim (Sam'āni, 1997).

Surat al-Nisā' merupakan surat ke-4 secara urutan di mushaf yang memiliki jumlah 176 ayat menurut kebanyakan mufassir dengan status surat Madaniyyah. Kecuali satu ayat dengan status Makkiyyah yaitu ayat 58. Surat ini menurut kesepakatan para ulama, turun di Madinah setelah turunnya surat Āli Imrān. Hal ini dikarenakan riwayat dari Aisyah yang mengatakan bahwa surat al-Nisā' ini turun ketika Nabi di samping Aisyah menandakan bahwa surat ini turun setelah Nabi menikahinya, dan ini terjadi di Madinah. Ibnu Abbas meriwayatkan bahwa yang pertama kali turun di Madinah adalah Surat al-Baqarah, lalu al-Anfāl, Āli Imrān, alAḥzāb, al-Mumtaḥanah, kemudian al-Nisā'. Dari sini surat al-Nisā' turun setelah perang alAḥzāb, yaitu pada akhir tahun ke-4 H, atau permulaan tahun ke-5 H. Sebagian ulama' mengatakan bahwa surat al-Nisā' turun ketika hijrah Nabi, bahkan sebagian pun juga berpendapat bahwa surat al-Nisā' ini adalah surat Makkiyah karena diawali dengan kalimat "yaa ayyuha al-Nās...". Tentu pendapat ini adalah pendapat yang kurang tepat, karena "yaa ayyuha al-Nās...", tidak menunjukkan status surat adalah Makkiyah, namun yang dimaksud di sini adalah bahwa penduduk Makkah termasuk dalam orang-orang yang dipanggil dalam surat/ayat tersebut. Justru pendapat yang lebih tepat adalah pendapat yang mengatakan bahwa surat al-Nisā' adalah surat Madaniyyah, atau turun setelah Nabi Hijrah, karena ia turun setelah surat Āli Imrān. Karakteristik surat al-Nisā' ini terkandung di dalamnya hukum-hukum Syariat yang detail dan ini tidak terjadi kecuali setelah Kaum Muslim tinggal secara stabil di Madinah (Ibnu 'Āshūr, 1984). Berbicara tentang sejarah turunnya surat al-Nisā', terjadi sedikit perbedaan yang telah dipaparkan secara global sebelumnya. Namun di sini terdapat tiga pendapat secara umum tentang sejarah turunnya. Pertama, bahwa surat al-Nisā' turun pada awal tahun ke-7 H. Pendapat ini berdasarkan catatan pada Fath al-Bārī yang menyebutkan bahwa yang pertama kali turun di Madinah adalah surat al-Baqarah, lalu alAnfāl, al-Aḥzāb, al-Māidah, al-Mumtaḥanah, kemudian al-Nisā'. Sementara surat alMumtahanah turun setelah peristiwa Perjanjian Hudaibiyyah di akhir tahun ke-6 H. Kedua, surat al-Nisā'turun pada masa antara perjanjian Hudaibiyyah dan perang Tabuk, yaitu antara tahun ke-7 H dan tahun ke-9 H. Pendapat ini merupakan pendapat Ibnu Hisyām dalam buku sejarahnya. Ketiga, bahwa mayoritas ayat surat al-Nisā' turun setelah Perang Uhud, yaitu setelah tahun ke-3 H. Keempat, surat al-Nisā' turun pada tahun ke-4 H. Kelima, surat al-Nisā' turun pada tahun ke-7 H dan berlangsung lama turunnya (Hisyām, 1955; Qattān, 2001). Dari pendapat-pendapat di atas, disimpulkan bahwa surat al-Nisā' bermula turun pada tahun ke-3 $\mathrm{H}$, lalu berlanjut hingga tahun ke-8 H. Hal ini karena tidak semua surat al-Qur'an turun sekali waktu. Terkadang satu surat turunnya berlangsung lama, terkadang berlangsung cepat hingga membentuk satu kesatuan surat yang utuh.

Adapun keutamaan surat ini terangkum dalam hadis Nabi dari Wātsilah ibnul Asqo', sesungguhnya Nabi s.a.w bersabda: "Aku telah dikaruniai $a l$-sab'u yang sebanding dengan kitab Taurat, aku juga diberi al-ma'inn yang sebanding dengan kitab Zabur, aku juga diberi almatsān̄ yang sebanding dengan Kitab Injil, dan aku dikaruniai kelebihan dengan almufashshal'. Hadis ini bercerita tentang salah satu karunia yang Allah berikan kepada Nabi, bahwa Nabi diberikan karunia salah satunya dengan al-Qur'an yang di dalamnya terdiri dari al-Sab'u al-Tiwāl adalah 7 surat yang panjang, di mana 7 surat ini sepadan dengan kitab 
Taurat. Ketujuh surat panjang ini adalah: al-Baqarah, Āli Imrān, al-Nisā', al-Māidah, alAn'ām, al-A'rāf dan Yūnus. Sehingga dari hadis ini diketahui bahwa keutamaan surat alNisā' adalah termasuk dalam bagian tujuh surat yang panjang dalam al-Qur'an (Baidhawi, 2010).

Surat al-Nisā' memiliki tema khusus yaitu mengajak kepada tauhid dan hal-hal yang menjadi konsekuensi ketauhidan, seperti bersikap adil, perintah jihad, dan perintah-perintah syariat yang berprinsip pada ketauhidan. Sebagaimana surat ini mengajak kepada penghapusan sifat-sifat jahiliyyah untuk menjadikan masyarakat Islam menjadi masyarakat yang bersih yang berbeda dari masyarakat lainnya. Selain itu, surat ini bertujuan untuk mengajak pembacanya berpegang teguh pada ajaran agama, mengajak kaumnya untuk menjaga 6 hal yaitu harta, nasab, badan, agama, lisan dan keimanan setelah di awal surat mengajak kepada sifat taqwa sebagai prinsip dari semuanya. Sebagaimana surat ini datang untuk menanamkan keutamaan akhlaq, bersifat adil dan menjaga martabat (Anjari, n.d.; Biqāi, n.d.). Selain itu, tema-tema yang diusung surat ini adalah hukum seputar anak yatim dan rumah tangga, menjaga kehormatan kaum wanita dengan cara berbuat baik padanya, dan memberikan hak-haknya secara penuh, hukum-hukum waris yang mencerminkan keadilan dan persamaan, mengajak pada taubat, tema terkait hubungan antara suami istri, juga membahas tentang hukum perkawinan dan hukum seputar rumah tangga kecil yang menjadi asas dan pokok dalam sebuah masyarakat. Sebagaimana surat ini juga membahas tentang hukum-hukum peperangan, dan kembali pada hukum Allah jika terjadi perselisihan. Tak lupa pula membahas tentang orang-orang munafik dan Nasrani yang telah melampaui batas.

\section{Hak Kesetaraan dengan Kaum Laki-Laki}

"Sesungguhnya kaum wanita adalah saudara bagi kaum laki-laki", begitulah hadis Nabi yang diriwayatkan dalam Musnad Ahmad bin Hanbal. Sebuah hadis pendek namun penuh makna dan ajaran bahwasanya dalam agama Islam kaum wanita dan laki-laki adalah setara. Bahkan ajaran Islam menekankan, bisa jadi seorang perempuan lebih dekat dan dicintai Allah karena ketakwaannya dari pada seribu laki-laki. Hadis ini pula memberikan sebuah indikasi bahwa kaum perempuan melengkapi kaum laki-laki dalam keberadaannya di sebuah masyarakat supaya dapat berjalan secara harmoni. Dalam surat al-Nisā', hak keseteraan ini terlihat dalam dua bentuk yaitu kesetaraan dalam asal penciptaan, dan kesetaraan dalam balasan di akhirat nanti.

Prinsip kesetaraan ini merupakan salah satu prinsip Islam yang menempatkan kaum perempuan pada tempatnya yang mulia (Ermagusti, 2011). Semua manusia baik laki-laki dan perempuan diciptakan dari asal yang sama, tiada beda di antara keduanya kecuali ketakwaan dan amalan shalih. Perhatikan dalam surat al-Nisā' (4) ayat pertama:

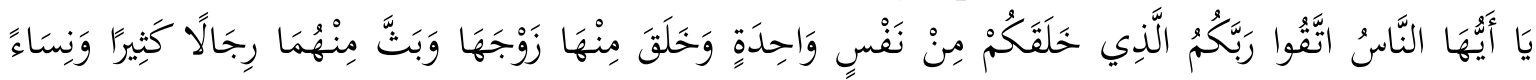

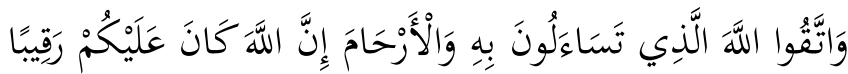

"Hai sekalian manusia, bertakwalah kepada Tuhan-mu yang telah menciptakan kamu dari seorang diri, dan dari padanya Allah menciptakan isterinya; dan dari pada keduanya Allah memperkembang biakkan laki-laki dan perempuan yang banyak. Dan bertakwalah kepada Allah yang dengan (mempergunakan) nama-Nya kamu saling meminta satu sama lain, dan (peliharalah) hubungan silaturrahim. Sesungguhnya Allah selalu menjaga dan mengawasi kamu”.

Pada ayat di atas terdapat pernyataan prinsip asal penciptaan yaitu pada kata “...dari seorang diri..." di mana prinsip ini menandaskan bahwa tidak ada kelebihan atas laki-laki kepada perempuan atau sebaliknya. Ayat ini menegaskan tentang kesetaraan pada asal

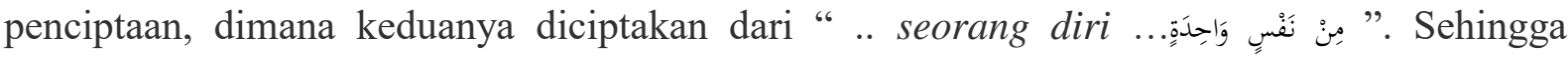


keduanya adalah sama-sama penciptaannya, dan Islam tidak melihat perempuan dengan pandangan hina karena asal penciptaannya. Pada permulaan surat al-Nisā' ini pula menunjukkan tentang keagungan Allah yang telah menciptakan keduanya dari diri yang sama, lalu menjadikan keduanya berkembang biak untuk memakmurkan bumi. Keseteraan dalam asal penciptaan ini bukan berarti keseteraan tanggung jawab, namun masing-masing memiliki peran dan tanggung jawab dalam pemakmuran dunia. Terdapat beberapa tafsiran terkait

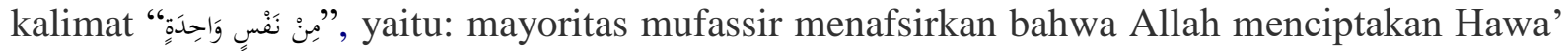
dari tulang rusuk Adam, sementara al-Rāzy menafsirkan bahwa antara Adam dan Hawa' diciptakan dari satu jenis dan satu hakikat (Sa'di, 2000). Ibnu Athiyyah dan al-Thobari menyebutkan bahwa yang dimaksud kalimat tersebut sesuai riwayat dari Mujahid dan Qatadah adalah Adam, bahwa laki-laki dan perempuan keduanya berasal dari asal yang sama yaitu Adam (Ibnu Athiyyah, 2001; Thobari, 2000), sebagaimana al-Suyuthi dan al-Baghawi berpendapat seperti ini berdasarkan riwayat Ibnu Abbas (Baghawi, n.d.; Suyūthiy, n.d.). Namun dari perbedaan ini penulis cenderung memilih pendapat al-Rāzy, karena dalam penciptaan dari jenis yang sama inilah, Allah memuliakan kaum perempuan, karena antara perempuan dan laki-laki diciptakan dari jenis yang sama, tanpa ada perbedaan. Di samping ketiadaan teks secara jelas baik dari al-Quran ataupun Hadis yang menyatakan bahwa kaum perempuan diciptakan dari tulang rusuk Adam, walau terdapat riwayat bahwa Hawa tercipta dari tulang rusuk, namun tidak secara jelas bahwa tulang rusuk tersebut adalah tulang rusuk Adam. Perbedaan ini tentu penting dalam menjelaskan bahwa perempuan diciptakan sama persis asal penciptaan laki-laki, dan Allah menyetarakan keduanya sejak mula penciptaannya. Bahkan banyak teks keagamaan mendukung pendapat yang menekankan persamaan unsur kejadian Adam dan Hawa, dan persamaan kedudukannya (Kurniawan, 2011). Demikian alQur`an menolak pandangan-pandangan yang membeda-bedakan laki-laki dan perempuan dengan menegaskan bahwa keduanya berasal dari jenis yang sama dan bahwa dari keduanya secara sama-sama Tuhan mengembangbiakkan keturunan yang baik laki-laki maupun perempuan (B \& Fahnum, 2017).

Prinsip kesetaraan berikutnya adalah prinsip kesetaraan dalam pahala/balasan di akhirat. Termasuk keadilan Islam menjadikan kesetaraan dalam pahala/balasan baik bagi kaum lakilaki ataupun perempuan karena keduanya adalah mukallaf atau diberi beban kewajiban baik itu berupa perintah ataupun larangan, bahwa keduanya akan dimintai pertanggungjawabannya dalam tiap amalannya. Dalam surat al-Nisā' secara jelas bahwa balasan amalan tidak terikat dengan jenis penciptaan: laki-laki atau perempuan, namun terikat oleh keimanan dan amal shalih. Hal ini sesuai pada surat al-Nisā'(4): 124 yaitu:

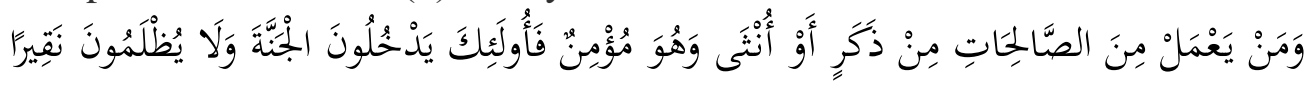

"Dan barangsiapa yang mengerjakan kebaikan, baik ia laki-laki atau perempuan sementara dia beriman, maka mereka akan masuk surga dan tidak didzalimi sedikitpun."

Ayat ini menunjukkan bahwa antara perempuan dan laki-laki diperintahkan untuk beribadah secara setara, kecuali ibadah-ibadah tertentu yang memang tidak sesuai kodrat perempuan, semisal: syariat perang, maka syariat ini khusus untuk kaum laki-laki, sementara kaum perempuan dimaafkan dan tidak dibebani secara langsung, bukan karena bentuk penghinaan namun justru salah satu bentuk pemuliaan. Ibnu Katsir, al-Thobari dan al-Suyuthi menyebutkan bahwa Allah menerima semua amal baik hambanya, baik laki-laki dan perempuan dengan syarat keimanan bukan syarat lainnya, dan bukan karena ia laki-laki ataupun perempuan. Sehingga keduanya memiliki kesempatan yang sama tanpa ada beda (Katsir, 2000: Suyūthiy, n.d.: Thobari, 2000). Kesetaraan ini pula terdapat dalam banyak ayat selain pada surat al-Nisā' ini juga banyak terdapat dalam hadis Nabi. Semisal surat al-Ahzab: 35 yaitu: 


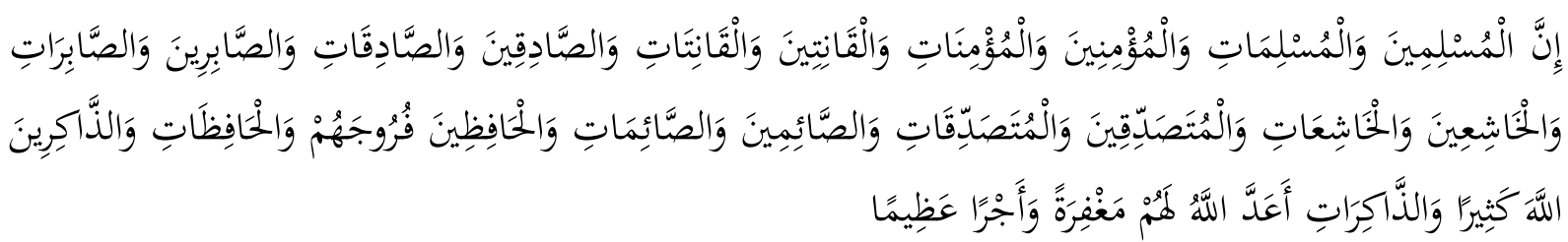

"Sesungguhnya laki-laki dan perempuan yang muslim, laki-laki dan perempuan yang mukmin, laki-laki dan perempuan yang tetap dalam ketaatannya, laki-laki dan perempuan yang benar, laki-laki dan perempuan yang sabar, laki-laki dan perempuan yang khusyu', laki-laki dan perempuan yang bersedekah, laki-laki dan perempuan yang berpuasa, laki-laki dan perempuan yang memelihara kehormatannya, laki-laki dan perempuan yang banyak menyebut (nama) Allah, Allah telah menyediakan untuk mereka ampunan dan pahala yang besar."

Sementara dari Hadis, seperti yang diriwayatkan oleh Ummu Salamah (Tirmidzi, 1998) bahwa ia berkata: "Ya Rasulullah, saya tidak mendengar Allah mengapresiasi hijrah para perempuan”. Kemudian Allah menurunkan QS. Ali Imran (3): 195 yaitu:

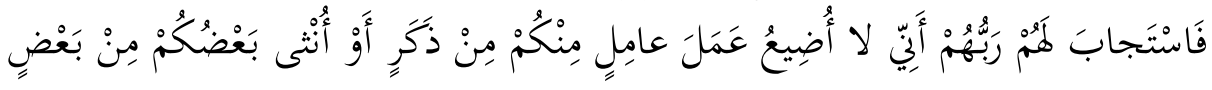

"Bahwa sesungguhnya Aku tidak akan membuang buang apa yang diperbuat setiap orang di antara kamu, baik laki-laki maupun perempuan, sebagian kamu dari sebagian yang lain”.

Dalam mengomentari hadis ini, Buya Faqih menjelaskan bahwa hadis Ummu Salamah ini hanya salah satu saja dari catatan-catatan kegelisahan perempuan pada masa awal Islam terhadap al-Qur'an yang secara literal tidak menyebut perempuan mengenai kiprah mereka dalam hal hijrah dan jihad, karena seperti diketahui bahwa ayat-ayat mengenai hal ini terkesan tidak memasukkan perempuan, karena bahasa Arab menggunakan struktur laki-laki (Kodir, 2017).

\section{Hak Memilih Pasangan dan Hak Untuk Bercerai}

Islam memberikan kepada perempuan hak untuk memilih calon suami. Kaum perempuan berhak untuk menerima pilihannya dan menolak yang tidak disukainya dalam perkawinan. Bahkan Islam melarang wali menikahkan secara paksa anak gadis dan saudara perempuannya dengan orang yang mereka tidak sukai serta menganggap pemaksaan dalam menentukan suami sebagai suatu kezaliman karena disamping melanggar hak azasi kaum perempuan, juga akan menimbulkan permusuhan dan perpecahan antara keluarga pihak perempuan dengan keluarga pihak laki-laki bila terjadi ketidakcocokan dalam perkawinan. Banyak hadis yang menyebutkan bahwa tidak boleh dikawinkan seorang perempuan sebelum dimintai pesetujuannya (Tahir, 2016). Di antara hadis-hadis ini adalah hadis Nabi pada riwayat al-Bukhari dari Abu Hurairah: "perempuan janda lebih berhak atas dirinya, daripada walinya perempuan gadis diminta izinnya dan izinnya adalah diamnya" (Asqalān̄̄, 1960). Atau barang kali hadis pada riwayat Ibnu Majah dari Abu Buraidah, dari ayahnya. Sang ayah berkata, ada seorang perempuan muda datang ke Nabi dan bercerita: "Ayah saya menikahkan saya dengan anak saudaranya untuk mengangkat derajatnya melalui saya". Nabi memberikan keputusan akhir di tangan perempuan. Lalu perempuan itu berkata: "Ya Rasul, saya rela dengan yang dilakukan oleh ayah saya, namun saya ingin mengumumkan kepada para perempuan bahwa ayah-ayah ini tidak memiliki hak untuk urusan ini" (Majah, n.d.).

Sementara pada surat al-Nisā' sendiri juga menegaskan tentang hak perempuan dalam memutuskan perceraian jika dalam pernikahan ternyata tidak ada ketercocokan, dan tidak dapat berjalan dengan baik, serta tidak dapat dipertahankan. Peristiwa yang terjadi malah sebaliknya, perselisihan dan cek-cok suami istri yang dapat menyebabkan terbengkalainya 
hak-hak Allah dalam sebuah pernikahan. Hak untuk memutuskan perceraian ini sebagaimana dimiliki oleh kaum laki-laki yaitu hak talak, maka iapun juga dimiliki kaum perempuan yaitu melalui gugat cerai. Keduanya memiliki hak yang sama dalam masalah perceraian. Sementara pada pihak kaum perempuan, Allah berfirman dalam surat al-Nisā': 130, yang artinya: "Jika keduanya bercerai, maka Allah akan memberi kecukupan kepada masing-masingnya dari limpahan karunia-Nya. Dan adalah Allah Maha Luas (karunia-Nya) lagi Maha Bijaksana". Ayat ini memberikan hak kepada perempuan untuk bercerai dengan suaminya bila ada alasannya (Thobari, 2000) Allah berfirman pada ayat ini dengan memakai kata ganti untuk berdua yaitu suami istri “...keduanya bercerai.." menunjukkan bahwa kaum perempuan seperti halnya laki-laki dalam keputusan bercerai. Sebagaimana dalam ayat ini Allah menjelaskan bahwasanya Allah Maha Luas karunia-Nya Bisa jadi Allah memberikan ganti untuk keduanya dengan pasangan yang lebih baik dan hendaknya keduanya bersangka baik kepada Allah (Qurțubi, 1964). Sebagaimana pada ayat lain dalam akhir ayat 19 surat al-Nisā' Allah berfirman: “...Kemudian bila kamu tidak menyukai mereka, (maka bersabarlah) karena mungkin kamu tidak menyukai sesuatu, padahal Allah menjadikan padanya kebaikan yang banyak." Dijelaskan di sini, bahwa jika seorang perempuan bercerai maka boleh jadi ia akan menemukan kebahagiaan bersama dengan pasangan yang lain menggantikan pernikahannya yang sebelumnya (Rāzy, 1999).

Jelas bahwa agama Islam mengangkat kezaliman-kezaliman sosial yang dialami seorang perempuan. Jika ia tidak kuat dalam rumah tangganya, maka ia memiliki hak untuk berpisah dengan suaminya. Mengutip pemahaman baru yang dihasilkan dari pemikiran Engineer yang disebutkan oleh Khairul Mufti Rambe (2017) bahwa nikah dalam Islam bersifat kontraktual. Dengan kata lain, baik pengantin laki-laki maupun pengantin perempuan dapat menetapkan syarat-syarat berlangsungnya pernikahan. Hal ini mengisyaratkan bahwa perempuan bebas untuk memutuskan apakah ia mau melakukan kontrak pernikahan atau tidak. Karena bersifat kontrak, perempuan bebas untuk mengajukan perceraian kapan pun ia mau, tentu bila ada alasan-alasannya.

\section{Hak Waris dan Hak Bertasarruf Terhadap Harta}

Islampun juga memberikan pengakuan terhadap "ahliyyah / kemampuan berbuat" secara sempurna kepada perempuan sebagaimana kepada laki-laki. Islam menetapkan hak bertasarruf terhadap hartanya dan melakukan transaksi-transaksi dalam semua jenisnya baik sewa menyewa, jual beli, hibah dan lain sebagainya sesuai dengan batasan-batasan syariat. Islam pun menghapus adat jahiliyah yang mengharamkan perempuan hak waris, dan kaum laki-laki kala itu selalu menyempitkan hak-hak perempuan dalam bertasarruf harta. Penghapusan ini terdapat pada surat an-Nisa (4): 7 yaitu:

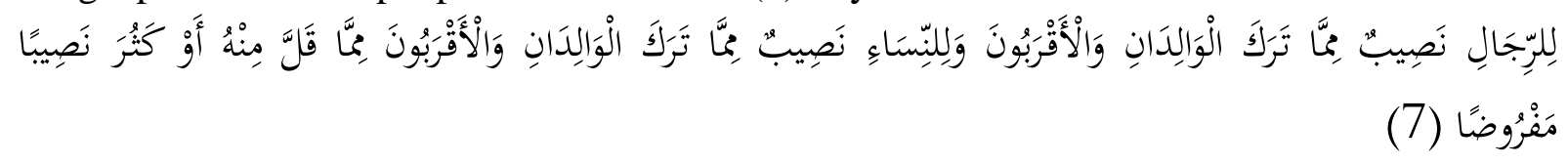

"Bagi orang laki-laki ada hak bagian dari harta peninggalan ibu-bapa dan kerabatnya, dan bagi orang wanita ada hak bagian (pula) dari harta peninggalan ibu-bapa dan kerabatnya, baik sedikit atau banyak menurut bahagian yang telah ditetapkan."

Al-Syaukān̄i ketika menafsirkan ayat ini berkomentar bahwa Allah menyendirikan penyebutan kaum perempuan setelah kaum laki-laki, dan tidak berkata bahwa kaum laki-laki dan perempuan memiliki hak bagian, namun disebutkan secara sendiri-sendiri. Ini menunjukkan bahwa kaum perempuan memilki hal secara permulaan, dan untuk menghapus pemikiran yang telah ada pada masa jahiliyyah bahwa kaum perempuan tidak memiliki hak waris. Ayat ini pun ditegaskan kembali oleh kalimat-kalimat pada akhir ayat "...baik sedikit 
atau banyak..." tentang hak perempuan dalam harta waris ini entah itu bagiannya sedikit atau banyak. Bagian ini tidak boleh diakhirkan dari bagian kaum laki-laki (Syaukāni, 1993). AlThobari dan Ibnu Athiyyah (Ibnu Athiyyah, 2001; Thobari, 2000) menyetir riwayat dari Ikrimah, bahwa ayat ini turun terkait Ummu Kahlah, anak perempuannya, suaminya yaitu Tsa'labah dan sepupu laki-lakinya. Ummu Kahlah berkata: "ya Rasulullah, suamiku wafat meninggalkan aku dan anak perempuan, sementara kami berdua tidak mendapatkan hak warisan". Lalu sepupunya berkata: "bagaimana dia dapat hak waris, sementara dia tidak ikut angkat senjata, berperang melawan musuh", lalu turunlah ayat ini. Al-Suyuthi menyebutkan riwayat dari Saib bin Jubair tentang ayat ini bahwa pada masa jahiliyyah sebelum Islam mereka tidak memberikan waris kepada kaum perempuan dan anak-anak kecil meskipun lakilaki, lalu turunlah ayat ini (Suyūthiy, n.d.). Dalam tafsirnya Abu Zahrah menegaskan bahwa ayat ini adalah prinsip umum dalam masalah warisan, dan bahwa hak waris adalah bukan semata hak kaum laki-laki, namun hak waris ini adalah hak bersama. Prinsip waris untuk kaum perempuan ini menghapuskan kezaliman yang terjadi terhadap perempuan pada masa lampau dan hak ini disebutkan sebanyak dua kali. Hak untuk laki-laki, lalu menjadi hak juga untuk perempuan sebagai penegasan dengan menyebutkan khusus kata al-nisā (Zahrah, n.d.). Hak mendapatkan waris ini dilakukan juga secara adil, sehingga wanita mendapatkan perlakuan yang adil. Jika terdapat hak waris, maka perempuan harus mendapatkan secara adil tanpa dikurangi. Surat al-Nisā' ayat 11 menegaskan: “...yaitu: bagian seorang anak lelaki sama dengan bagian dua orang anak perempuan;... " Allahpun berfirman dalam ayat 32 pada surat yang sama:

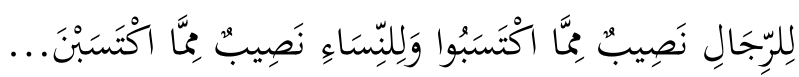

“...bagi orang laki-laki ada bahagian dari pada apa yang mereka usahakan, dan bagi para wanita (pun) ada bahagian dari apa yang mereka usahakan..”

Di sini ditegaskan bahwa kaum perempuan memiliki hak sama persis dengan kaum lakilaki dalam berusaha dan bekerja mencari harta serta hak memiliki harta. Hal ini menunjukkan bahwa kaum perempuan memiliki ahliyyah secara sempurna sebagaimana kaum laki-laki. Adapun harta yang diusahakan oleh kaum perempuan entah itu dengan cara bekerja atau melalui hibah. Harta ini adalah merupakan haknya secara penuh yang bebas ia bertasarruf terhadapnya. Tiada yang boleh mengambilnya secara zalim siapapun itu, bahkan orang yang terdekat hubungannya dengannya.

Berbicara tentang hak perempuan untuk mendapatkan warisan, kaum perempuan sebelum Islam yang tertindas hak-haknya, dijadikan seperti barang yang bisa diwariskan. Karena ini ketika agama Islam datang, melalui surat al-Nisa': 19 Allah melarang untuk menjadikan wanita sebagai barang warisan.

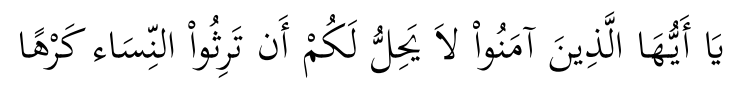

"Hai orang-orang yang beriman, tidak halal bagi kamu mempusakai wanita dengan jalan paksa..."

Ibnu Katsir (1419: 209) menjelaskan tentang sebab turunnya ayat ini, yaitu pada masa sebelum Islam jika seorang laki-laki meninggal, maka wali atau keluarga laki-laki ini lah yang berhak terhadap istri laki-laki yang telah meninggal. Jika di antara wali/keluarga ini mau menikah dengan mantan istri ini maka akan dinikahi, jika mereka berkendak merekapun bisa menikahkan si perempuan ini dengan siapa saja yang mereka suka. Jika mereka berkehendak, mereka pun tidak akan menikahkan perempuan ini dengan siapa saja, karena mereka ini adalah yang paling berhak terhadap perempuan ini. Lalu turunlah ayat ini sebagai larangan kepada mereka supaya mereka tidak menjadikan para perempuan ini sebagai barang pusaka. Riwayat yang lain pada tafsir yang sama juga menjelaskan bahwa kaum laki-laki pada masa 
itu mewarisi istri dari keluarganya yang telah meninggal, hingga si istri ini meninggal atau mengembalikan maharnya kepada keluarga si laki-laki, lalu Allah melarangnya dengan adanya ayat ini. Ikrimah menjelaskan dalam riwayat lain terkait ayat ini bahwa ayat ini turun pada kasus Kubaisyah binti Ma'ni bin 'Ashim dari suku al-Aus yang mana suaminya "Abu Qoim bin al-Aslat" telah wafat. Anak Abu Qosim ini menahannya, lalu ia datang kepada Nabi dan berkata: "Ya Rasulullah, aku tidak mendapatkan warisan dari suamiku, dan aku juga tidak dibiarkan hingga aku dapat menikah", lalu turunlah ayat ini. Sehingga jelaslah, bahwa sebelum Islam datang, kaum wanita ini tidak mendapatkan hak waris apa-apa, namun justru malah diwariskan.

Dalam surat al-Nisā' ini dijelaskan dengan detail hak-hak kaum perempuan untuk mendapatkan waris. Baik dia sebagai anak perempuan, sebagai istri, sebagai ibu, atau sebagai saudara perempuan. Masing-masing kondisi terdapat bagiannya masing-masing yang dijelaskan dalam ayat ini, dan lebih jelas lagi dikupas dalam fiqih farā'iḍ yang membahas tentang sistem kewarisan Islam. Tentu hak waris yang dimiliki dan dinikmati oleh kaum perempuan memiliki hikmah yang sangat banyak, di antaranya adalah: pertama, karena Islam memberikan keseteraan hak antara kaum laki-laki dan perempuan, sebagaimana Islam memberikan hak waris kepada laki-laki, maka begitu pula dengan perempuan. Kedua, karena sebagai manusia, entah itu laki-laki atau perempuan, maka keduanya sama-sama memiliki naluri rasa cinta terhadap harta, sehingga Islam memberikan haknya terkait waris untuk mencukupi kebutuhan mereka.

\section{Hak Mendapatkan Perlakuan yang Baik}

Di antara urgensi pernikahan adalah untuk membangun institusi keluarga dan menanggung bersama tugas dan tanggung jawab kehidupan atau "berbareng berjuang". Perjuangan itu berupa penciptaan ketenangan, kedamaian dan benteng penjaga stabilitas temperatur batin pihak-pihak yang terlibat di dalamnya. Terakhir adalah wahana pelanggengan regenerasi. Di antara hak perempuan khususnya dalam hukum keluarga adalah untuk mendapatkan perlakukan yang baik dari suami dalam pergaulan hidup berumah tangga. Prinsip pergaulan dan kehidupan yang aman, damai, tenteram, sejahtera dan penuh asih ini dapat dilihat dalam sejumlah ayat al-Qur'an, (Tahir, 2016) dan dinyatakan secara penuh oleh surat al-Nisā' (4) pada sebagian ayat 19 yaitu:

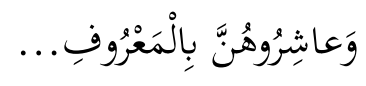

\section{“... Dan bergaullah dengan mereka secara patut.."}

Perlakuan baik terhadap istri ini tidak hanya dengan mencukupi kebutuhan materi saja, namun lebih dari itu, bagaimana suami dapat bergaul dengan penuh rasa cinta dan kasih sayang sehingga tercipta rasa ketersalingan dalam mendidik anak-anak dan membina rumah tangga. Lebih menarik lagi, bahwa ayat ini disebutkan dalam kondisi ketika suami sedang dalam perasaan benci kepada istri. Maka pada saat ini, seolah-olah Allah memberikan arahan pada para suami untuk tetap berlaku baik kepadanya. Di samping tentu perlakuan baik suami kepada istri juga termasuk salah satu sikap kesempurnaan agama seseorang, dan sebaliknya perlakuan tidak baik suami kepada istri adalah termasuk kekurangan seseorang. Al-Thobari meriwayatkan dari Abu Ja'far bahwa salah satu jenis mu'āsyarah bil ma'rūf adalah dengan memenuhi hak-hak para istri secara baik dalam ikatan rumah tangga. Bila ingin dicerai, pun dilakukan dengan cara-cara yang baik pula (al-Thobari, 2000: 121). Ibnu Katsir menafsirkan tentang ayat ini, yaitu supaya suami memperlakukan istri dengan baik sebagaimana para suami juga ingin diperlakukan istri dengan baik (Katsir, 2000). Hadis-hadis yang memperkuat ayat ini sangat banyak, di antaranya adalah hadis dari al-Aswad bin Yazid, bahwa ia berkata: Saya bertanya kepada Aisyah mengenai apa yang diperbuat Nabi di dalam rumahnya. Aisyah 
menjawab: "Ia melayani keluarganya, ketika datang waktu shalat, ia bergegas pergi shalat" (Ibnu Hazm, n.d.). Hadis lain yang tak kalah pentingnya adalah hadis Nabi: "Sebaik-baik kalian adalah yang paling baik kepada istrinya" (Majah, n.d.).

Adapun bentuk perlakuan baik kepada istri sangat banyak, dan kesemuanya telah dicontohkan sang Nabi dalam tindakannya terhadap istrinya. Juga dalam ucapannya yang kesemuanya terabadikan dalam hadis-hadisnya. Kesemuanya terekam dalam hadis Nabi: "Berlakulah baik terhadap istri kalian" (Ibnu Hazm, n.d.) sebagai bentuk tafsiran dari QS alNisā'(4): 11. Perlakuan baik ini tidak terbatas pada rumah tangga dengan satu istri, namun dalam rumah tangga poligami perlakuan baik ini lebih ditekankan lagi khususnya dalam masalah keadilan. Karena sejatinya prinsip pernikahan adalah monogamy. Pernikahan poligami adalah pengecualian, dan jika itu terjadi maka prinsip keadilan antara istri harus dinomorsatukan. Hal ini adalah sesuai perintah Allah dalam surat al-Nisā' (4): 3, yaitu:

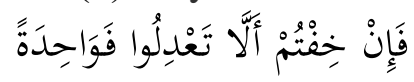

“...Kemudian jika kamu takut tidak akan dapat berlaku adil, maka (kawinilah) seorang saja,..."

Rasa adil di sini adalah rasa adil yang dapat diukur oleh manusia, yaitu adil yang dapat dilihat dan ditimbang yang sifatnya lahiriah dan kuantitatif, misalnya: pakaian, tempat tinggal, uang belanja, dan hari kebersamaan (giliran). Sedangkan yang sifatnya kualitataif semisal rasa maka hanya Allah yang tahu (Ainiyah, 2017). Keadilan ini tidak mungkin dapat diukur dan dipenuhi oleh manusia sekalipun si pelaku berniat untuk melakukan itu, seperti dalam surat al-Nisā' (4) : 129 di bawah ini:

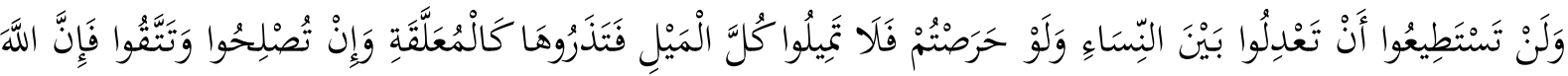
كَانَ غَغْورًا رَحِيمًا

"Dan kamu sekali-kali tidak akan dapat berlaku adil di antara isteri-isteri(mu), walaupun kamu sangat ingin berbuat demikian, karena itu janganlah kamu terlalu cenderung (kepada yang kamu cintai), sehingga kamu biarkan yang lain terkatungkatung. Dan jika kamu mengadakan perbaikan dan memelihara diri (dari kecurangan), maka sesungguhnya Allah Maha Pengampun lagi Maha Penyayang."

Ayat di atas adalah sebagai peringatan akan beratnya pelaksanaan syariat ini: adil dalam rumah tangga poligami. Bahkan terdapat ancaman bagi pelaku poligam yang tidak bisa berbuat adil yaitu digambarkan datang di hari akhir dengan pundak yang miring, seperti yang diriwayatkan oleh Abu Hurairah (Abu Dawud, n.d.). Karena ini Nabi dalam rumah tangganya selalu membagi giliran dan berdoa: "Ya Allah inilah bagianku yang dapat aku kerjakan. Karena itu, janganlah Engkau mencelakakanku tentang apa yang Engkau kuasai, sedang aku tidak menguasainya". Para ulama berkata bahwa yang dimaksud di sini adalah keadilan dalam masalah hati (Abu Dawud, n.d.).

\section{Hak Mendapatkan Mahar}

Engineer seperti yang dikutip oleh Khairul Mufti Rambe, memiliki pandangan tersendiri tentang mahar, dimana mahar ini bukanlah harga perempuan. Mahar juga bukan menunjukkan kelas sosial. Mahar bukan berarti seperi jual beli, karena sejatinya dalam pernikahan adalah terdapat ketersalingan. Mahar adalah ungkapan rasa cinta, ketulusan, dan kesungguhan. Walau demikian mahar tetap menjadi bagian dari esensial perkawinan, karena mahar adalah hak perempuan yang harus dibayar oleh suami. Wanita bebas menentukan jumlah maharnya yang dia sukai dan mahar itu menjadi miliknya, bukan milik ayah atau suaminya, pemahaman tersebut merujuk kepada Q.S al-Nisā' (4): 4 


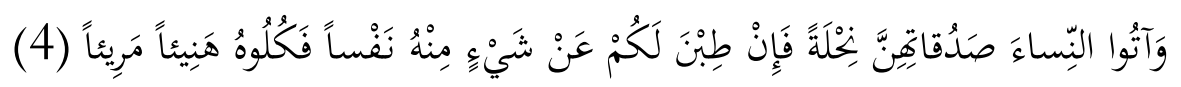

"Berikanlah maskawin (Mahar) kepada perempuan (yang kamu nikahi) sebagai pemberian dengan penuh kerelaan", Namun jika mereka menyerahkan kepada kamu sebagian dari mahar itu dengan kerelaan, maka makanlah (ambillah) pemberian itu (sebagai makanan) yang sedap lagi baik akibatnya."

Dari ayat ini muncul penafsiran bahwa tidak ada batasan dalam menentukan jumlah besarnya mahar. Al-Qur'an juga mengajarkan agar laki-laki memberikan mahar sebanyak mungkin sesuai dengan kemampunnya (Rambe, 2017). Allah wajibkan mahar ini dengan adanya akad nikah, sebagai bentuk pemuliaan perempuan dan juga sebagai salah satu jaminan berlangsungnya kehidupan rumah tangga ke depannya. Seorang suami akan berpikir ulang tentang perceraian jika ia berpikir kembali tentang perjuangannya dalam membayar mahar ini. Pemberian mahar ini sifatnya adalah pemberian wajib yang pertama seorang suami kepada istrinya pada waktu akad nikah, yang menandakan bahwa di sana akan ada kewajibankewajiban materi yang berikutnya selama masa hubungan pernikahan setelah pembayaran mahar. Dengan adanya pembayaran mahar ini suami dipersiapkan untuk menghadapi kewajiban-kewajiban yang sifatnya materi pada tahap berikutnya (Syarifuddin, 2014). Kewajiban memberi mahar atas kaum laki-laki merupakan lambang perlindungan dan kasih sayang kepada perempuan, agar dia tidak mempertaruhkan kehormatannya sekedar mendapatkan harta benda, atau mau menikah karena mempertimbangkan mahar tersebut, seakan-akan mahar itu lah yang ia cari (B \& Fahnum, 2017).

Ayat ini pula menghapus realita yang terjadi pada masyarakat Arab di mana para wanita kala itu tidak mendapatkan mahar, namun wali lah yang menerima dan berhak atasnya. Atau bahkan suami ini tidak memberikan mahar, atau memakainya tanpa kerelaannya. Justru Islam datang menghapus semuanya, dan menetapkan bahwa perempuanlah yang berhak atas mahar, tiada satupun yang boleh menggunakannya tanpa ijin dan kerelaan si perempuan pemilik mahar. Terkait ayat ini Ibnu Athiyyah dalam tafsirnya menukil riwayat dari Ibnu Shalih bahwa kata perintah pada ayat di atas diperuntukkan bagi para wali dari kaum perempuan, karena biasanya di masa jahiliyyah, para wali inilah yang menggunakan secara bebas mahar anaknya perempuan, tanpa ijin, sehingga dengan ayat ini Allah menghapus kezaliman terkait hak kaum perempuan (Ibnu Athiyyah, 1422:8). Sementara al-Baghawi menambahkan, bahwa perintah pada ayat ini selain untuk para wali, maka ayat ini juga diperuntukkan untuk para suami, dan ini lebih dekat dengan kebenaran karena pada ayat sebelumnya berbicara tentang pelaku perkawinan, yaitu suami (Baghawi, n.d.).

Ibnu Hazm (n.d.) berkomentar tentang ayat di atas terkait hak perempuan dalam mahar serta menegaskan bahwa orang lain tidak berhak atasnya: "Tidak halal bagi ayah seorang gadis, baik masih kecil maupun sudah besar, juga ayah seorang janda dan anggota keluarga lainnya, menggunakan sedikit pun dari mahar putri atau keluarganya. Tidak sorang pun yang kami sebutkan di atas, berhak untuk memberikan sebagian mahar itu, tidak kepada suami baik yang telah menceraikan ataupun belum (menceraikan), tidak pula kepada yang lainnya. Siapa yang melakukan demikian, maka itu adalah perbuatan yang salah dan tertolak selamanya." Namun jika hal ini atas ijin si perempuan, maka sah-sah saja karena dalam hal ini mendapatkan ijin dari pemilik mahar itu sendiri, seperti yang tersebut dalam ayat tersebut di atas: "...namun jika mereka menyerahkan kepada kamu sebagian dari mahar itu dengan kerelaan, maka makanlah (ambillah) pemberian itu (sebagai makanan) yang sedap lagi baik akibatnya." 


\section{KESIMPULAN}

Surat al-Nisā' dengan status surat Madaniyyah, dengan urutan ke-4 dari urutan mushaf ini terkandung didalamnya banyak hukum, salah satunya yaitu terkait hak-hak kaum perempuan. Khususnya dalam masalah hukum keluarga. Surat ini menjelaskan banyak hak kaum perempuan, di antaranya yaitu hak kesetaraan dengan kaum laki-laki, hak memilih pasangan dan bercerai, hak waris dan bertasarruf harta, hak mendapatkan perlakuan yang adil, serta hak mendapatkan mahar. Hak-hak tersebut ini sebelum Islam datang menjadi hak yang tidak diperhatikan bahkan hak-hak ini tergerus oleh budaya patriarki di mana kaum perempuan selalu menjadi golongan yang termajinalkan. Hak-hak ini pula yang selalu digaungkan oleh mereka, pembela emansipasi perempuan, dan sejatinya agama Islam telah mengaturnya sedemikian rupa, tidak ada kezaliman atas kaum perempuan. Justru Islam memuliakan kaum perempuan dengan menyatakan hak-haknya secara jelas dalam surat alNisā'. Sehingga dari sini, sudah seharusnya dalam perlakuan kehidupan bermasyarakat, atau relasi suami istri tidak boleh terjadi ketimpang tindihan/pelecehan terhadap hak-hak perempuan.

\section{REFERENSI}

Abu Dawud, S. bin al-Asy'ats. (n.d.). Sunan Abi Dawud. al-Maktabah al-Asriyyah.

Agustina, A. M. (2017). HAK-HAK PEREMPUAN DALAM PENGARUSUTAMAAN RATIFIKASI CEDAW DAN MAQĀȘID ASY-SYARI'AH. Al-Ahwal: Jurnal Hukum Keluarga Islam, 9(2), 201-210. https://doi.org/10.14421/ahwal.2016.09205

Ainiyah, Q. (2017). Keadilan Gender dalam Islam: Konvensi PBB dalam perspektif Mazhab Shafi' $i \quad$ (Malang). Intrans $/ / 10.170 .10 .3 /$ index.php?p=show_detail\&id=96152\&keywords=

Anjari, A. bin M. al. (n.d.). Al-Bahr al-Madīd fi Tafsīr al-Qur'an al-Majīd.

Asqalānī, I. Hajar al. (1960). Fatḥ al-Bārī. Dār al-Ma'rifah.

B, N., \& Fahnum, M. A. (2017). HAK-HAK PEREMPUAN MENURUT PERSPEKTIF ALQURAN. Marwah: Jurnal Perempuan, Agama Dan Jender, 16(2), 186-200. https://doi.org/10.24014/marwah.v16i2.4139

Baghawi, H. bin M. al. (n.d.). Ma'ālim al-Tanzīl (1999th ed.). Dār Ihyā' Turāts al-Arabiy.

Baidhawi, M. bin A. al. (2010). Al-Tibyān fì mā shaḥha fì fadhāil suwar al-Qur'ān. Dar alIstiqāmah.

Biqāi, I. bin U. al. (n.d.). Nidzām al-Durar Fi Tanāsub al-Āyat wa al-Suwar. Dar al-Kutub alIslamiy.

Cholil, M., \& Sudirman, S. (2019). GENDER EQUALITY IN ISLAMIC FAMILY LAW: Breaking the Chain of Domestic Violence to Achieve Harmonious Family. Kafa ah: Journal of Gender Studies, 9(2), 131-146-146. https://doi.org/10.15548/jk.v9i2.270

Ermagusti, E. (2011). PRINSIP KESETARAAN GENDER DALAM ISLAM. Kafa $a h$ : Journal of Gender Studies, 1(2), 187-196-196. https://doi.org/10.15548/jk.v1i2.78

Hisyām, I. (1955). Al-Sīrah al-Nabawiyyah. Musthafa al-Baby al-Halaby.

Ibnu Athiyyah, A. H. bin G. (2001). Al Muharrar al Wajīz fì Tafsīr al Kitāa al Azīz. Dār Kutub al-Ilmiyyah.

Ibnu Ḥazm, A. bin A. (n.d.). Al-Muhallā bi al-Ātsār. Dār al-Fikr.

Ibnu 'Āshūr, M. T. bin M. (1984). Al-Tahrīr wa al-Tanwīr. Dār al-Tunisiyyah.

Katsir, I. ibn. (2000). Tafsir al-Qur'an al-Adzim. Dar ibn Hazm. 
38 | Volume 10, No. 1, Januari-Juni 2020

Kodir, F. A. (2017). 60 hadis hak-hak perempuan dalam Islam: Teks dan interpretasi. Umah Sinau Mubadalah.

Kurniawan, N. (2011). HAK ASASI PEREMPUAN DALAM PERSPEKTIF HUKUM DAN AGAMA. Jurnal Konstitusi, 4(1), Article $1 . \quad$ http://publishingwidyagama.ac.id/ejournal-v2/index.php/jk/article/view/304

Majah, I. (n.d.). Sunan Ibnu Mājah. Dār Ihyā' Kutub al-Arabiyyah.

Qasimy, M. J. bin Q. al. (1998). Maḥāsin al-Ta'wīl. Dār al-Kutub al-Islāmiyyah.

Qattān, M. al. (2001). Tārikh Tasyrī' al-Islāmiy. Maktabah Wahbah.

Qurțubi, M. bin A. al. (1964). Tafsīr al-Qurțubi. Dār al-Kutub al-Misriyyah.

Rambe, K. M. (2017). Hak-Hak Perempuan Dalam Hukum Islam (Studi Pemikiran Ashgar Ali Engineer). JURNAL MERCATORIA, 10(2), 109-127. https://doi.org/10.31289/mercatoria.v10i2.1095

Rāzy, F. al. (1999). Mafātiḥul Ghaib. Dār ihyā' al-Turāts al-Araby.

Rusli, M. (2011). KONSEP GENDER DALAM ISLAM. Kafa `ah: Journal of Gender Studies, 1(2), 151-158-158. https://doi.org/10.15548/jk.v1i2.75

Sa'di, A. bin N. al. (2000). Taysīr al-Karīm al-Raḥmān fì tafsī̄ kalām al-mannān. Muassasat al-Risalah.

Sam'āni, M. bin M. al-Maruzi al. (1997). Tafsīr al-Sam 'āni. Dār al-Watan.

Sarbini, M. (2017). HAK-HAK WANITA DALAM FIQIH ISLAM. Al-Mashlahah Jurnal Hukum Islam dan Pranata Sosial, 5(09), Article 09. https://doi.org/10.30868/am.v5i09.184

Suyūthiy, J. al. (n.d.). Al-Durr al-Mantsūr fì al-Tafsīr bi al-Ma'tsūr. Dār al-Fikr.

Syarifuddin, A. (2014). Hukum perkawinan Islam di Indonesia: Antara fiqh munakahat dan Undang-Undang Perkawinan. Prenadamedia group.

Syaukāni, M. bin A. al. (1993). Fath al-Qadir. Dar Ibnu Katsīr.

Tahir, M. (2016). PEREMPUAN DALAM BINGKAI HAK ASASI MANUSIA DALAM HUKUM KELUARGA ISLAM. Musãwa Jurnal Studi Gender Dan Islam, 15(1), 5975. https://doi.org/10.14421/musawa.2016.151.59-75

Thobari, A. J. M. bin J. al. (2000). Jāmi' al-Bayān fi Tafsīr al-Qur'ān. Mu'assasat al-Risalah.

Tirmidzi, T. (1998). Sunan al-Tirmīdzi. Dar al-Gharb al-Islāmy.

Zahrah, A. (n.d.). Zahrah al-Tafasir. Dar al-Fikr al-'Arabi. 